\title{
Interleukin-1 $\beta$ Stimulates Transendothelial Mobilization of Human Peripheral Blood Mononuclear Cells with a Potential to Differentiate into Osteoclasts in the Presence of Osteoblasts
}

\author{
YASUHIDE TOKUKODA, Shoichiro TAKATA, Hiroshi KAJI, RiKo KITAZAWA*, \\ TOSHITSUGU SUGIMOTO AND KAZUO CHIHARA
}

Third Division, Department of Medicine, Kobe University School of Medicine, 7-5-1 Kusunoki-cho, Chuo-ku, Kobe 6500017, Japan

* Second Department of Pathology, Kobe University School of Medicine, 7-5-1 Kusunoki-cho, Chuo-ku, Kobe 650-0017, Japan

\begin{abstract}
There is accumulating evidence that interleukin-1 (IL-1) levels are increased locally at the site of active bone resorption in a variety of diseases including osteoporosis, periodontal disease and rheumatoid arthritis. However, the pathogenic role of IL-1 in bone loss remains to be fully elucidated. We present here additional evidence that IL-1 $\beta$ enhances endothelial activation and thereby stimulates mobilization of peripheral blood mononuclear cells (PBMCs) from luminal to abluminal spaces across the endothelium. Furthermore, IL- $1 \beta$ stimulates the differentiation of PBMCs into osteoclast-like cells with bone-resorbing activity in the presence of human osteoblastic SaOS-2 cells without systemic hormones. These findings provide circumstantial evidence for the hypothesis that IL-1 $\beta$ generated in the bone microenviroment plays a stimulatory role in PBMC mobilization from the peripheral circulation and their subsequent differentiation into osteoclast-like cells in the bone tissue. In addition, the present study supports the notion that osteoclast progenitor cells might be derived from the peripheral circulating blood mononuclear cells in human.
\end{abstract}

Key words: IL-1 $\beta$, Monocyte, Osteoclast, Endothelial cell, Osteoclast formation

(Endocrine Journal 48: 443-452, 2001)

OSTEOCLASTS can be generated from premature hematopoietic cells such as granulocytes/macrophage colony-forming units which can also differentiate into monocytes/macrophages [1, 2]. However, the details of the osteoclast cell lineage remain unclear. Based on the structural characteristics that capillary vessels run in all directions within the bone architecture, it is plausible that circulating osteoclast

Received: February 28, 2001

Accepted: April 23, 2001

Correspondence to: Dr. Toshitsugu SUGIMOTO, Third Division, Department of Medicine, Kobe University School of Medicine, 7-5-1 Kusunoki-cho, Chuo-ku, Kobe 650-0017, Japan. precursors transmigrate across capillary vessel walls and subsequently differentiate into osteoclasts. Although premature hematopoietic cells can scarcely be detected, mononuclear phagocytes are relatively abundant in the peripheral circulation. Therefore, it is conceivable that mononuclear phagocytes are preferable as a source of osteoclasts. A previous study [3] suggested that osteoclast precursors are present in the circulation of osteopetrotic mice. Moreover, avian [4], murine [5, 6] and human [7-9] monocytes in the peripheral blood can differentiate into osteoclast-like cells.

In pathological states accompanied by bone loss such as osteoporosis, periodontal disease and rheu- 
matoid arthritis, recent attention has been focused on cytokines including interleukin-1 (IL-1) generated in the bone microenvironment that may be responsible for stimulating osteoclastic bone resorption $[10,11]$. Several studies suggested that increased IL-1 production by human peripheral blood mononuclear cells (PBMCs) is responsible for development of osteoporosis $[12,13]$. It has been also reported that increased osteoclastogenesis and bone resorption in ovariectomized mice was inhibited by IL-1 receptor antagonists, suggesting that endogenous IL-1 plays an important role in osteoclastic bone resorption in vivo [14]. These findings raised the hypothesis that various cells including mononuclear phagocytes in the bone microenviroment produce IL-1, and thereby enhance transmigration of peripheral monocytes through capillary vessel walls to the extravascular spaces in the bone tissue and stimulate their differentiation into osteoclasts. To test this hypothesis, we established an in vitro model system to mimic the bone microenvironment. First, we examined the effects of IL- $1 \beta$ on the recruitment of human PBMCs across human umbilical vein endothelial cells (HUVECs) toward cultured SaOS-2 cells, human osteoblastic cells. Second, we examined whether IL-1 $\beta$ would induce the differentiation of human PBMCs into the cells with osteoclastic characteristics in the presence of SaOS-2 cells.

\section{Materials and Methods}

\section{Isolation of PBMCs and labeling with ${ }^{51} \mathrm{Cr}$}

Human PBMCs containing monocytes were isolated by density gradient separation on a Ficoll-Paque cushion (Pharmacia, Uppsala, Sweden) from heparinized venous blood drawn from normal volunteers. Monocytes were enriched by allowing the PBMCs to adhere to the tissue culture plates for $90 \mathrm{~min}$ in RPMI1640/10\% bovine calf serum (BCS) (Life Technologies Inc., Grand Island, NY). At this stage, the cells were usually labeled with ${ }^{51} \mathrm{Cr}$ sodium chromate $(40 \mu \mathrm{Ci} / \mathrm{ml})$ (Amersham, Buckinghamshire, U.K.) for both transmigration and adhesion experiments. Suspended cells and cells loosely attaching to the plastic surface were removed by three washes with RPMI $/ 10 \%$ BCS. Adherent cells were collected with $0.2 \%$ EDTA $/ 5 \%$ BCS and two rinses with RPMI $1640 / 10 \% \mathrm{BCS}$ at $4^{\circ} \mathrm{C}$. More than $95 \%$ of the cells in this fraction were positively stained for nonspecific esterase (NSEase), a monocyte marker.

\section{HUVECS}

HUVECs were isolated and propagated as described previously [15]. Briefly, cells were dispersed by $0.1 \%$ collagenase (CLS 3; Worthington Biochemical Corp, Freehold, NJ) and propagated in RPMI 1640 medium supplemented with 15\% BCS, 15\% NU-serum (Collaborative Research Inc., Bedford, MA), $50 \mathrm{mg} / \mathrm{ml}$ endothelial mitogen (Biomedical Technologies Inc., Stoughton, MA), $8 \mathrm{U} / \mathrm{ml}$ heparin, $50 \mathrm{U} / \mathrm{ml}$ penicillin and $50 \mu \mathrm{g} / \mathrm{ml}$ streptomycin. HUVECs were characterized based on morphological criteria and by indirect immunofluorescence assay using a specific antiserum to human factor VIII antigen, and studied at passage levels 2 and 3 .

\section{Migration of PBMCs across HUVEC monolayers}

For studies of transmigration, HUVECs were grown to confluence in HUVEC medium on gelatincoated (1\%) Transwell polycarbonate filters containing $5 \mu \mathrm{m}$ pores (Costar, Cambridge, MA), which were inserted into 24 well tissue culture plates (Costar, Cambridge, MA), as described previously [16]. SaOS-2 cells were grown to confluence on 24well plates, unless otherwise specified. The HUVEC monolayer and filter divided each well into an upper "luminal" (100 $\mu \mathrm{l})$ and lower "abluminal" compartment $(600 \mu \mathrm{l})$. For IL-1 $\beta$ stimulation, HUVECs and /or SaOS- 2 cells were preexposed to IL- $1 \beta$ or its vehicle for the indicated times. After the preexposure, they were washed once with PBS/1\% BCS. Transmigration was initiated by addition of ${ }^{51} \mathrm{Cr}$-labeledPBMCs $\left(100 \mu 1,3 \times 10^{4} \mathrm{PMN}\right)$ to the luminal compartment. Assays were performed in a humidified atmosphere containing $5 \% \mathrm{CO}_{2} / 95 \%$ air at $37^{\circ} \mathrm{C}$ and were terminated by aspiration of non-adherent PBMCs from the luminal compartment, removing transwell inserts from the abluminal compartment, and washing PBMCs that were loosely adherent to the undersurface of filters into the abluminal chamber with $1 \mathrm{ml}$ of PBS $\left(4^{\circ} \mathrm{C}\right)$ without $\mathrm{Ca}^{2+}$ and $\mathrm{Mg}^{2+}$. The rate of PBMC migration to the abluminal compartment was calculated by the lysis of cells with $0.5 \%$ Triton $\mathrm{X}-100$, and then the radioactivity 
was measured with a $\gamma$-counter and the counts compared to the specific activity of the original PBMC suspension. Unless otherwise stated, results are expressed as the percentage of ${ }^{51} \mathrm{Cr}$-labeled-PBMCs added to the luminal compartment migrated to the abluminal compartment. Agonist-stimulated transmigration was calculated by subtraction of transmigration observed in the presence of diluent.

\section{Adhesion of PBMCs either to HUVECs or SaOS-2 cells}

For studies of adhesion, HUVECs and SaOS-2 cells were grown to confluence on gelatin-coated (1\%) and uncoated 96 well plates (Costar, Cambridge, MA), respectively. For IL- $1 \beta$ stimulation, monolayers were preexposed to IL- $1 \beta$ or its vehicle for the indicated times. After the preexposure, they were washed once with PBS/1\% BCS. Cells were coincubated with $0.1 \mathrm{ml}$ of ${ }^{51} \mathrm{Cr}$-labeled PBMCs suspension $\left(3 \times 10^{4} \mathrm{PMN} /\right.$ well $)$ in a humidified atmosphere containing $5 \% \mathrm{CO}_{2} / 95 \%$ air at $37^{\circ} \mathrm{C}$ for the indicated times. Assays were terminated by removal of nonadherent cells by aspiration of medium and wash of monolayers with $0.2 \mathrm{ml}$ of $\mathrm{PBS} / 1 \% \mathrm{BCS}$. The contents of each well were solubilized with $0.01 \% \mathrm{SDS} / 0.025 \mathrm{~N} \mathrm{NaOH}$, and the radioactivity was measured in a $\gamma$-counter. The adherent PBMCs (\% of PBMCs added to each well) was calculated from the specific activity of each PBMC preparation.

\section{Characterization of osteoclast-like multinucleated cells}

At the end of the culture of PBMCs with SaOS-2 cells for the indicated times, cells were fixed and stained for tartrate-resistant acid phosphatase (TRAP) utilizing a commercial kit (Sigma, St. Louis, MO). TRAP-positive cells with three or more nuclei were counted as multinucleated cells (MNCs). Expression of calcitonin receptors was also assessed by autoradiography using ${ }^{125}$ I-human calcitonin (Amersham). For this assay, human PBMCs were cocultured with confluent SaOS- 2 cells on chamber slides in the presence of IL-1 $\beta(1 \mathrm{ng} / \mathrm{ml})$ for 4 weeks. The cells were fixed with paraformaldehyde (1\%) for $1 \mathrm{hr}$ at room temperature, washed once with PBS, and incubated with $0.2 \mathrm{nM}$ of ${ }^{125} \mathrm{I}$-calcitonin in the presence or absence of $1 \mu \mathrm{M}$ cold human calcitonin
(Peptide Institute Inc., Osaka, Japan). After washing ten times with $\mathrm{PBS} / 0.1 \% \mathrm{BSA}$, the cells were fixed again with fixative solution containing acetone (66\%) and paraformaldehyde (3\%) for $30 \mathrm{sec}$. After washing, the cells were stained for TRAP, dipped in LM-1 emulsion (Amersham), exposed at $4^{\circ} \mathrm{C}$ for 1 week and developed.

\section{Resorption pit formation}

The character of MNCs was further demonstrated by assessing their ability to form resorption pits on dentine slices as described previously [17]. In brief, dentine was cut into slices and the slices were put into 96-well plates. Isolated PBMCs $\left(3 \times 10^{5}\right.$ cells/well) were spotted on SaOS-2 cells, which had been grown to confluence on the dentine slices. After cells were cocultured for 4 weeks in the presence or absence of IL-1 $\beta(1 \mathrm{ng} / \mathrm{ml})$, the dentine slices were fixed and stained for TRAP to confirm the formation of TRAP-positive MNCs [TRAP(+) MNCs]. After removing adherent cells, the dentine slices were stained with hematoxylin solution. Resorption pits on the dentine slices were assessed by light microscopy.

\section{Reagents and monoclonal antibodies (mAbs)}

Recombinant human IL-1 $\beta$ were purchased from R \& D Systems (Minneapolis, MN). LTB 4 was obtained from Sigma Chemical Co. (St. Louis, MO). The following mAbs were used to assess the function of adhesion molecules: $\mathrm{mAb} \mathrm{SG} / 19\left(\mathrm{IgG}_{1}\right)$ which recognizes the $\beta$ subunit of $\beta_{1}$-integrins (Seikagaku Corp. kagaku Corp., Tokyo, Japan); and $\mathrm{mAb}$ MHM23 (IgG1) which recognizes $\beta$ subunit of $\beta_{2}$-integrin (DAKO, Glostrup, Denmark).

\section{Statisticl analysis}

Results were expressed as the mean \pm SEM. Oneway analysis of variance and Fisher protected LSD test were used for statistical analysis. A p value of $<0.05$ was taken to represent a statistically significant difference between groups. Data of figures were the representative of at least three separate cell preparations from different individuals. Similar results were obtained fll preparations. 


\section{Results}

\section{$I L-1 \beta$ stimulates transendothelial migration of PBMCs toward SaOS-2 cells}

In several previous studies, monocytes were cocultured only with endothelial monolayers for their transmigration experiments $[18,19]$. To reproduce their transmigration in bone tissue, we established a coculture system consisting of three different cells: PBMCs, HUVECs and SaOS- 2 cells. HUVECs monolayers, grown on polycarbonate filters containing $5 \mathrm{~mm}$ pores, prevented the passage of most ${ }^{51} \mathrm{Cr}$ labeled-PBMCs during PBMC-endothelium coincubation for $2 \mathrm{hr}$ (migration in $120 \mathrm{~min}, 5.01 \pm 0.26 \%$ $[\mathrm{n}=19])$. Pretreatment of both HUVECs and SaOS- 2 cells with IL-1 $\beta$ induced a rapid and concentration-dependent $\left(\mathrm{ED}_{50}=25.6 \mathrm{pg} / \mathrm{ml}\right.$, maximal at $1 \mathrm{ng} / \mathrm{ml}$ ) migration of PBMCs from luminal to abluminal compartments (Fig. 1). To examine possible mediation of the action of IL- $1 \beta$ on SaOS- 2 cells and/or its direct action on PBMCs for their migration across HUVECs toward SaOS-2 cells, we performed the experiments as shown in Fig. 2. First, we assessed each transendothelial migration of PBMCs when either HUVECs, SaOS-2 cells, or HUVECs and SaOS- 2 cells, had been pretreated with $1 \mathrm{ng} / \mathrm{ml}$ of IL-1 $\beta$ for $4 \mathrm{hr}$ (Fig. 2, upper panel). When HUVECs, or HUVECs and SaOS-2 cells, had been pretreated with IL- $1 \beta$, the transendothelial migration of PBMCs was equally induced in each case, but it was not induced when only SaOS- 2 cells had been pretreated with IL- $1 \beta$, indicating that PBMCs did not migrate through the action of IL- $1 \beta$ on SaOS- 2 cells. Second, we assessed the transendothelial migration of PBMCs for $2 \mathrm{hr}$ at $37^{\circ} \mathrm{C}$ after the addition of IL- $1 \beta$ $(1 \mathrm{ng} / \mathrm{ml})$ or $\mathrm{LTB}_{4}\left(10^{-8} \mathrm{M}\right)$, either to the upper or lower compartment (Fig. 2, lower panel). $\mathrm{LTB}_{4}$ induced a rapid migration of PBMCs through HUVEC monolayers when it was added to the lower compartment, but not when added to the upper one, indicating that $\mathrm{LTB}_{4}$ is a potent chemoattractant for monocytes as previously reported [20]. In contrast, the migration of PBMCs was not stimulated with IL- $1 \beta$ in either case, suggesting that the transendothelial migration of PBMCs did not occur through the direct action of IL- $1 \beta$ on PBMCs. Several reports $[18,19]$ revealed that transmigration of monocytes across IL-1ß-activated HUVECs was
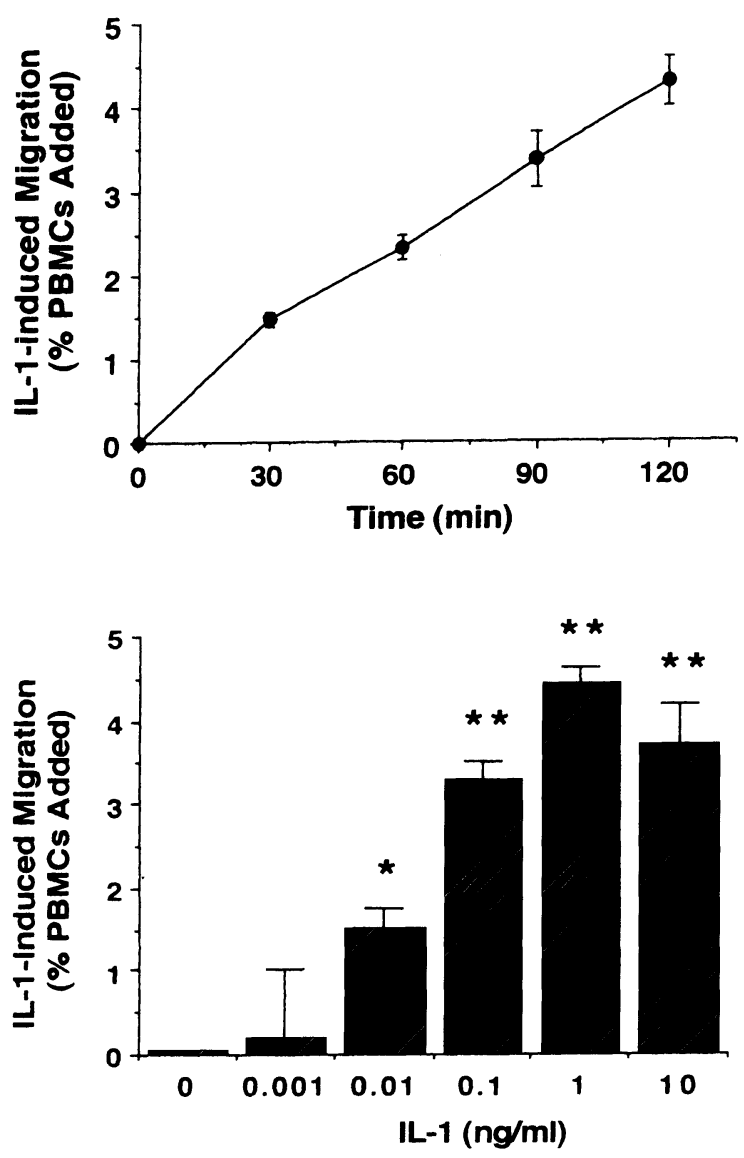

Fig. 1. Effects of IL-1 $\beta$ on migration of PBMCs across HUVEC monolayers. Migration of ${ }^{51} \mathrm{Cr}$-labeled PBMCs $\left(3 \times 10^{4} /\right.$ well $)$ across confluent monolayers of HUVEC was assessed as described in Materials and Methods.

(Upper Panel) HUVECs and SaOS-2 were exposed to IL-1 $\beta(1 \mathrm{ng} / \mathrm{ml})$ for $4 \mathrm{hr}$ and washed once with PBS/1\% BCS, followed by coincubation with ${ }^{51} \mathrm{Cr}$ labeled PBMCs in the upper compartment of Transwell plates for the indicated time.

(Lower Panel) HUVECs and SaOS-2 were exposed to the indicated concentrations of IL-1 $\beta$ for $4 \mathrm{hr}$ and washed once, before coincubation $(2 \mathrm{hr})$ with PBMCs. PBMCs transmigration is expressed as the percentage of PBMCs added to the upper compartment that migrated to the lower compartment. IL$1 \beta$-induced transmigration was calculated by subtraction of transmigration observed in control. Data are means \pm SEM of three experiments. ${ }^{*} \mathrm{p}<0.05$, ${ }^{* *} \mathrm{p}<0.001$ versus control.

mainly dependent upon $\beta 2$-integrin. In the present study, we confirmed it (data not shown). We also confirmed $\beta 2$-integrin-dependency of PBMCs adhesion to IL-1ß-activated HUVECs (data not shown). 

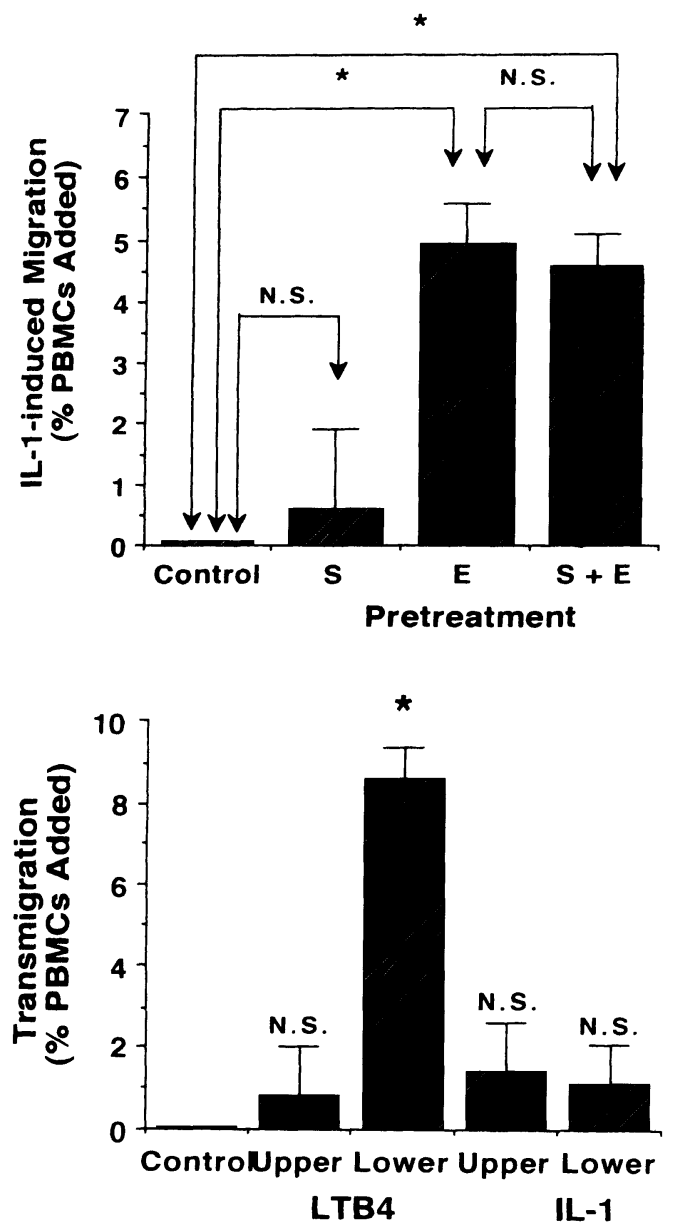

Fig. 2. IL-1 $\beta$ action is mediated through HUVECs. (Upper panel) Either SaOS-2 cells (S), HUVECs (E) or both $(\mathrm{S}+\mathrm{E})$ were exposed to IL-1 $\beta(1 \mathrm{ng} / \mathrm{ml})$ for $4 \mathrm{hr}$ and washed once with PBS/1\% BCS. Transendothelial migration of PBMCs was assessed as described in Materials and Methods. Transmigration is expressed as the percentage of PBMCs added to the upper compartment that migrated to the lower compartment. IL-1 $\beta$-induced transmigration was calculated by subtraction of transmigration observed in control. Data are means \pm SEM of three experiments. The comparison was made between the groups as indicated by arrows. N.S., not significant; ${ }^{*} \mathrm{p}<0.01$. (Lower panel) PBMCs transmigration was assessed $2 \mathrm{hr}$ after respective addition of $\mathrm{LTB}_{4}$ $\left(10^{-8} \mathrm{M}\right)$ and IL-1 $\beta(1 \mathrm{ng} / \mathrm{ml})$ either to upper or lower compartment. Transendothelial migration of PBMCs was assessed as described in Materials and Methods. Transmigration is expressed as the percentage of PBMCs added to the upper compartment that migrated to the lower compartment. Agoniststimulated transmigration was calculated by subtraction of transmigration observed in control. Data are means \pm SEM of three experiments. N.S., not significant; ${ }^{*} \mathrm{p}<0.0001$ versus control.

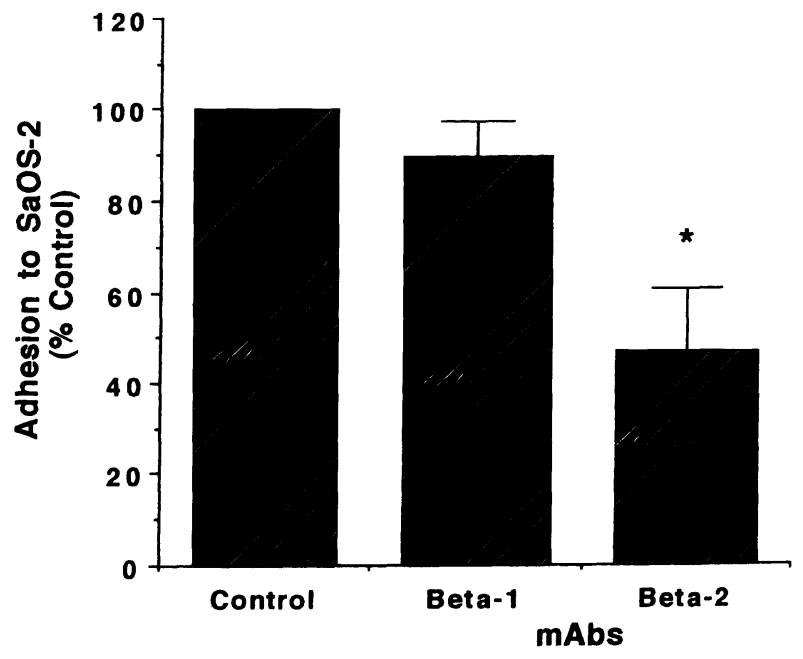

Fig. 3. $\beta_{2}$-integrin dependence of adhesion of PBMCs to SaOS-2 cells. ${ }^{51} \mathrm{Cr}$-labeled PBMCs were incubated with or without saturating concentration $(20 \mu \mathrm{g} / \mathrm{ml})$ of monoclonal antibodies(mAbs) against $\beta_{1}$ (beta1) or $\beta_{2}$ (beta2)-integrin for $15 \mathrm{~min}$ before and during coincubation with SaOS-2 cells. PBMCs adhesion to SaOS-2 cells was assessed as described in Materials and Methods and expressed as a percentage of adhesion observed with PBMCs in control. Data are means \pm SEM of three experiments. ${ }^{*} \mathrm{p}<0.005$ versus control.

\section{Spontaneous adhesion of PBMCs to SaOS-2 cells}

The anchoring of PBMCs to stromal cells including osteoblasts is essential to the fusion of PBMCs to form polykaryocytes such as osteoclasts. We therefore examined the adhesion of PBMCs to SaOS-2 cells with or without prior exposure of SaOS-2 cells to IL-1 $\beta(1 \mathrm{ng} / \mathrm{ml})$ (data not shown). PBMCs timedependently adhered to SaOS- 2 cells. In contrast to the adhesion of PBMCs to HUVECs, their adhesion to SaOS-2 cells was not stimulated by the pretreatment of SaOS- 2 cells with IL- $1 \beta$. Spontaneous adhesion of PBMCs to SaOS-2 cells was partially but significantly inhibited by prior exposure of PBMCs to mAb (NHM23) against the common $\beta$-subunit of $\beta_{2}$-integrins, but not by prior exposure of PBMCs to $\mathrm{mAb}(\mathrm{SG} / 19)$ against the common $\beta$-subunit of $\beta_{1^{-}}$ integrins (Fig. 3). 


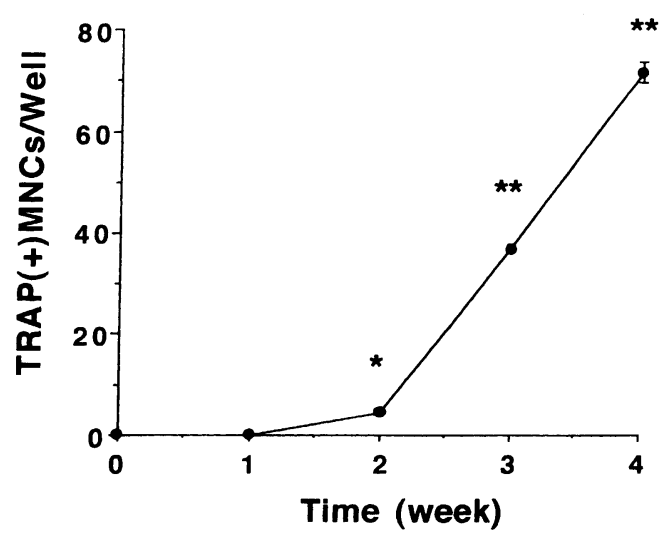

Fig. 4. Effects of IL- $1 \beta$ on formation of TRAP( + ) MNCs from PBMCs cocultured with SaOS-2 cells. SaOS-2 cells were grown to confluence on 96-well tissue culture plates. Human PBMCs $\left(10^{5} /\right.$ well) in the monocyte fraction were cocultured with SaOS- 2 cells in the presence of $\mathrm{IL}-1 \beta(1 \mathrm{ng} / \mathrm{ml})$ for the indicated times. TRAP-positive cells with three or more nuclei were counted as multinucleated cells. Number of TRAP $(+)$ MNCs per each well was counted. Data are means \pm SEM of three separate experiments. ${ }^{*} \mathrm{p}<0.01,{ }^{* *} \mathrm{p}<0.0001$ versus control.

\section{$I L-1 \beta$ stimulates the formation of TRAP-positive MNCs from PBMCs cocultured with SaOS-2 cells}

We examined whether PBMCs cocultured with SaOS-2 cells would differentiate into cells with osteoclastic characteristics. Isolated PBMCs at the 1st day of isolation were positively stained for nonspecific esterase $(>95 \%)$, but not for TRAP. IL- $1 \beta$ stimulated the formation of TRAP-positive mononuclear cells from PBMCs after 1 week coculture with SaOS-2 cells and subsequently stimulated the formation of TRAP $(+)$ MNCs in a time-dependent manner (2-4 weeks) (Fig. 4). Even in the absence of SaOS- 2 cells in culture, IL- $1 \beta$ stimulated both adhesion of PBMCs to tissue culture plates and formation of TRAP-positive mononuclear cells in 1-2 weeks, but not their fusion to form polykaryocytes. The adherent mononuclear cells to the tissue culture plates were almost completely detached within 3 weeks. Fig. 5a shows autoradiographs of the binding of human ${ }^{125}$ I-calcitonin to both TRAP-positive mono- or bi-nuclear cells, and TRAP $(+)$ MNCs 4 weeks after coculture of PBMCs with SaOS-2 cells in the presence of IL-1 $\beta(1 \mathrm{ng} / \mathrm{ml})$. Repetitive examination revealed that dense grains due to the binding of ${ }^{125}$ I-calcitonin appeared on approximately $30 \%$ of TRAP-positive mono- or bi-nuclear cells, and approximately $60 \%$ of TRAP $(+)$ MNCs. Simultaneous addition of an excess of unlabeled calcitonin completely removed the accumulation of dense grains from TRAP-positive cells (Fig. 5b). The formation of TRAP(+) MNCs after 4 week coculture was inhibited significantly by concomitant incubation of calcitonin $\left(10^{-8} \mathrm{M}\right)$ (data not shown). To further demonstrate osteoclast-like identity of MNCs, we assessed their ability to form resorption pits on dentine slices. When PBMCs were cocultured with confluent SaOS-2 cells on dentine slices in the presence of IL-1 $\beta(1 \mathrm{ng} / \mathrm{ml})$ for 4 weeks, lacunar resorption pits were formed, but not in the absence of IL- $1 \beta$ (Fig. 6).

\section{Discussion}

In bone tissue, monocytes are often found in the extravascular spaces adjacent to bone-resorbing surfaces [21], although their precise origin and roles in bone remodeling remain to be determined. Monocyte infiltration is thought to be triggered by various chemoattractants and cytokines including IL-1 [18, 19]. Increased secretion levels of IL-1 activity by PBMCs have been reported in postmenopausal women [13]. Concentration levels of IL-1 secreted by PBMCs from patients with periodontal disease [22] and those in tissues from sites of periodontal disease [1] are $0.45-13.00 \mathrm{ng} / \mathrm{ml} / 10^{6}$ cells $/ 24 \mathrm{~h}$ and approximately $11 \mathrm{ng} / \mathrm{ml}$, respectively. Taken together with the present findings that IL- $1 \beta$ at as low as $0.01 \mathrm{ng} / \mathrm{ml}$ induced transendothelial migration of PBMCs (maximum at $1 \mathrm{ng} / \mathrm{ml}$ ), the increased peripheral levels of IL-1 in patients of disease with bone loss seem to be sufficient for the recruitment of PBMCs across capillary vessel walls. Since monocytes [23], HUVECs [24] and SaOS-2 cells [25] have the specific receptors for IL-1, it is possible to speculate that the IL- $1 \beta$ stimulated recruitment of PBMCs across HUVEC monolayers is mediated through the action of IL-1 $\beta$ on any of the three kinds of cells. The present study revealed that the IL-1 $\beta$-stimulated migration is not mediated through its action on either PBMCs or SaOS-2 cells, but through its action on HUVECs. The present results were consistent with previous reports that transendothelial migration of leukocytes 


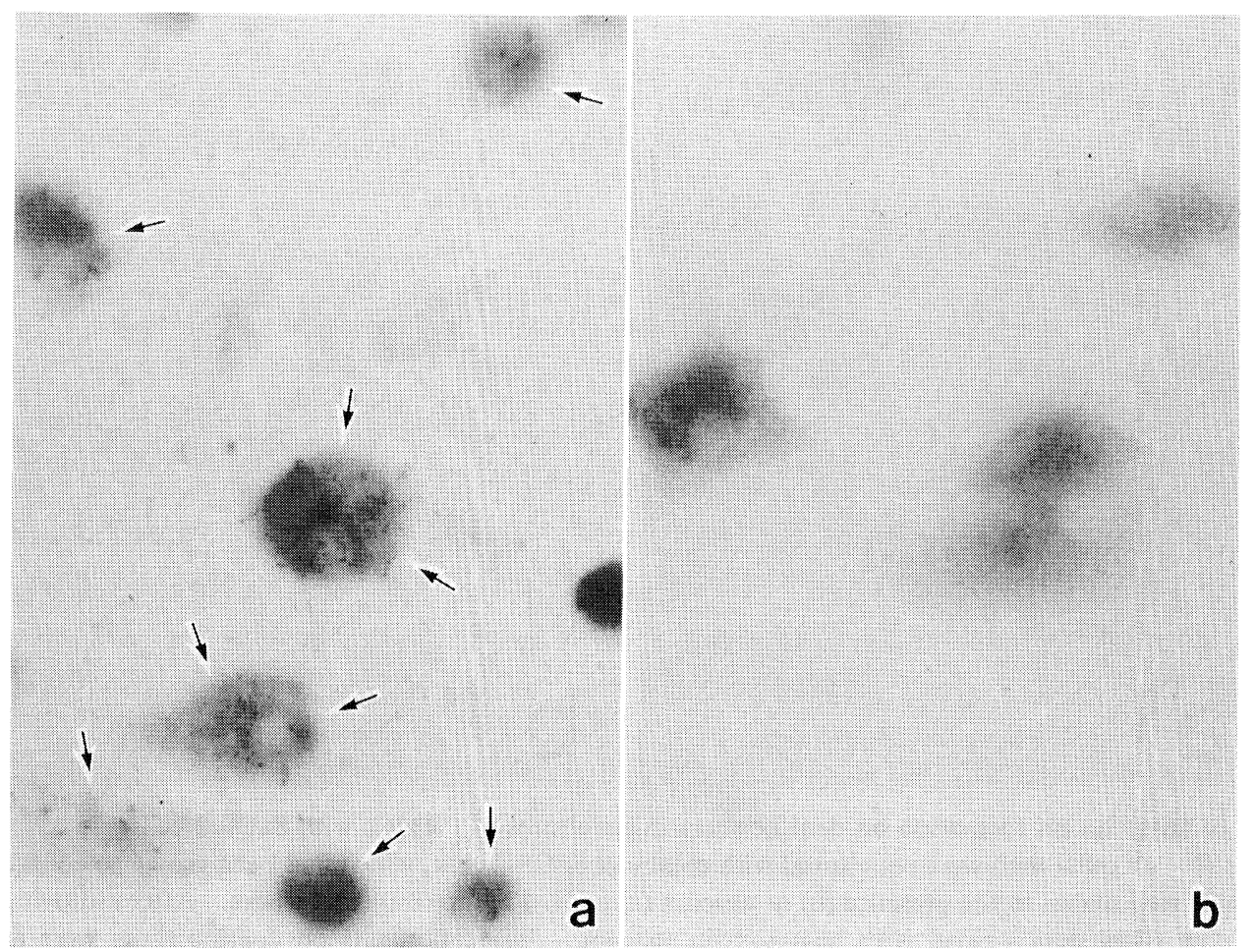

Fig. 5. Autoradiographs of of ${ }^{125} \mathrm{I}$-calcitonin binding to TRAP $(+)$ cells. PBMCs $\left(10^{5} /\right.$ well $)$ were cocultured with SaOS-2 cells in 96-well tissue culture plates for 4 weeks in the presence of IL-1 $\beta(1 \mathrm{ng} / \mathrm{ml})$. Autoradiography was performed after $1 \mathrm{~h}$ incubation with ${ }^{125} \mathrm{I}$-human calcitonin $(0.2 \mathrm{nM})$ at $4{ }^{\circ} \mathrm{C}$ in the absence (a) or presence (b) of excess of unlabeled calcitonin as described in Methods. Binding was observed in both mono- and multi-nucleated TRAP-positive cells as indicated by arrows.

including monocytes occurred through the activation of endothelium with IL-1 $[18,19]$. Once penetrated across endothelium, PBMCs should migrate through extravascular spaces and anchor to stroma and/or stromal cells including osteoblasts. In the present study, PBMCs spontaneously adhered to SaOS-2 cells in part through $\beta_{2}$-integrin. Although initial ( $<90 \mathrm{~min}$ ) adherence of PBMCs to HUVECs was stimulated by prior exposure of HUVECs to IL- $1 \beta$

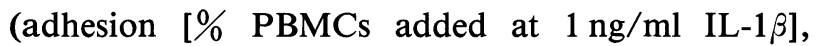
Control $0 \pm 1.0 \%$, IL-1 $25 \pm 0.96 \% *,{ }^{*} \mathrm{p}<0.0001$ versus control; $n=4)$, their initial ( $<90 \mathrm{~min}$ ) adherence to SaOS- 2 cells was not stimulated by prior exposure of SaOS- 2 cells to IL- $1 \beta$. These findings indicated that IL- $1 \beta$ did not affect adhesiveness of SaOS- 2 cells for PBMCs. However, the adherence of PBMCs to SaOS-2 cells in a later phase (1-2 weeks) was stimulated with IL-1 $\beta$. Since the adherence of PBMCs to tissue culture plates was also stimulated with IL-1 $\beta$ in $1-2$ weeks, the IL- $1 \beta$ en- hancement of their adherence to SaOS-2 cells in the later phase should be at least in part through its action on PBMCs. It has been also reported that IL-1 activates monocytes through its type II receptor to induce both gene expression and synthesis of various cytokines including tumor necrosis factor- $\alpha$ (TNF- $\alpha$ ) [26]. Taken together with the previous evidence that TNF- $\alpha$ is directly chemotactic for both monocytes and polymorphonuclear leukocytes [27], activating factors including TNF- $\alpha$ released from PBMCs in response to IL-1 $\beta$ might be involved in the enhancement of PBMC adherence to SaOS-2 cells in the later phase. The present study employed HUVECs as a model for transendothelial migration in bone. Since these cells are derived from large vessels through which no cell migration takes place in vivo, we cannot completely rule out the possibility that PBMCs might not transmigrate through small vessel endothelium after IL-1 stimulation. Moreover, the vessels in bone tissues are mostly sinusoids, which are 

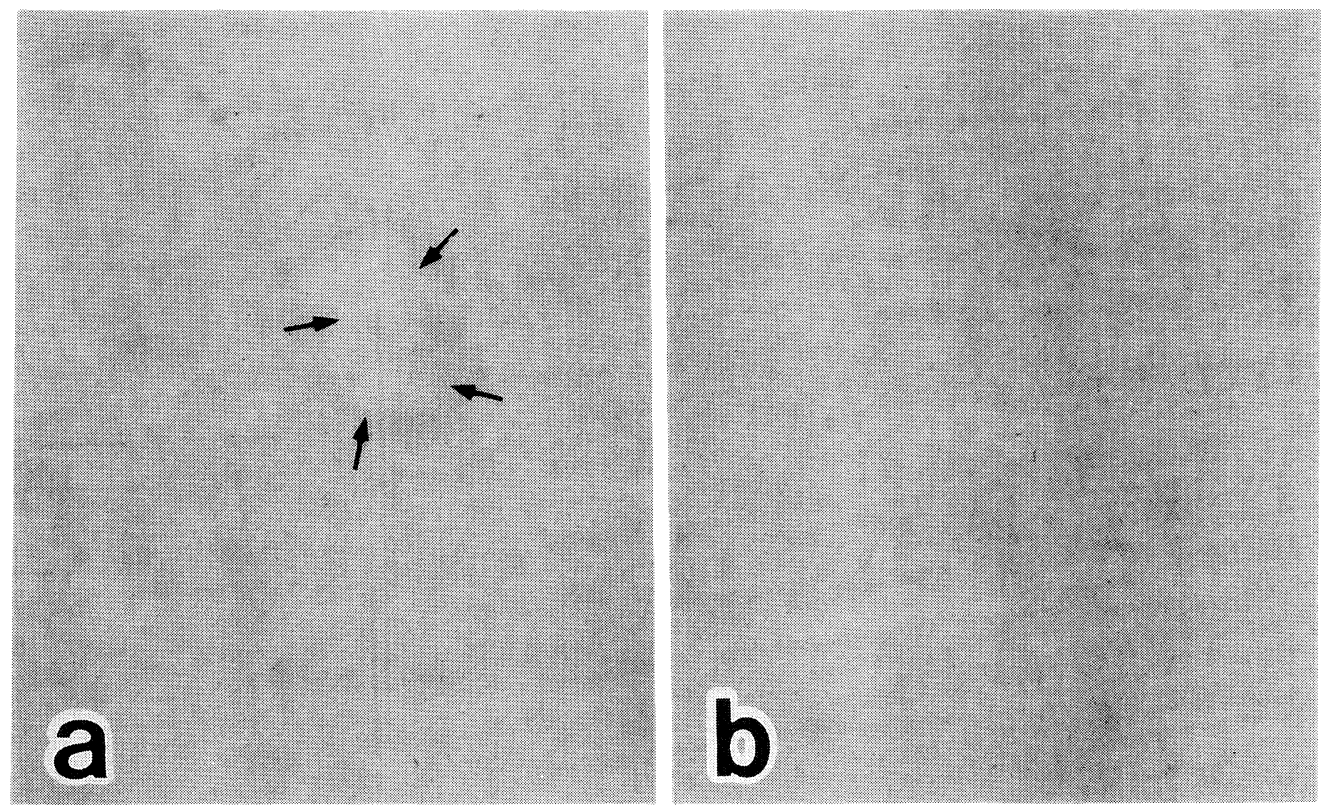

Fig. 6. Effects of IL- $1 \beta$ on pit formation on dentine slices in cocultures of PBMCs with SaOS-2 cells.

PBMCs $\left(3 \times 10^{5}\right.$ cells/well) were cocultured with confluent SaOS- 2 cells, which had been grown to confluence on dentine slices in 96-well plates, in the presence (b) or absence (a) of IL-1 $\beta(1 \mathrm{ng} / \mathrm{ml})$ for 4 weeks. After removing adherent cells, the dentine slices were stained with hematoxylin solution. Resorption pits on dentine slices were assessed by light microscopy $(\times 400)$.

composed of vascular endothelium lacking the basement membrane. Therefore, the mechanism of cell migration might be different from that with HUVECs.

In the present study, long-term (4 weeks) coculture of PBMCs with SaOS- 2 cells in the presence of IL-1 $\beta$ $(1 \mathrm{ng} / \mathrm{ml})$ induced their differentiation into TRAP and functional calcitonin receptor positive MNCs with bone-resorbing activity. TRAP( + MNCs derived from human PBMCs cocultured with SaOS-2 cells in the presence of IL-1 $\beta$ not only responded to calcitonin, but also induced lacunar bone resorption. These results indicate that the MNCs formed in the present study were not macrophage polykaryons, but mature osteoclasts or cells closely related to osteoclasts. In the present study, IL-1 $\beta$ itself stimulated adhesion of PBMCs to tissue culture plates and formation of TRAP-positive mononuclear cells in 1-2 weeks, but the adherent TRAP-positive mononuclear cells on tissue culture plates were almost completely detached within 3 weeks of coculture, indicating that only IL-1 $\beta$ or activating substances from PBMCs in response to IL- $1 \beta$ are not sufficient in themselves for the differentiation of PBMCs into TRAP( + ) MNCs. On the other hand, IL- $\beta$ in- duced full differentiation of PBMCs into osteoclastlike cells in the presence of SaOS- 2 cells. These results indicate that both IL-1 $\beta$ stimulation and presence of SaOS-2 cells are essential for the full differentiation of PBMCs into osteoclast-like cells. Although the present study could not determine the precise mechanism of PBMC differentiation into osteoclast-like cells, we can raise several possibilities by which PBMCs differentiate into osteoclast-like cells. One possibility is that the contact between PBMCs and SaOS-2 cells induced intracellular biological events through adhesion receptors on PBMCs, leading to their differentiation into osteoclast-like cells. In fact, PBMCs spontaneously adhered to SaOS-2 cells partly through $\beta_{2}$-integrin. Cell adhesion receptors including integrins function in the signal transduction process leading to the regulation of cell growth and differentiation [28]. Another possibility is that soluble factors released from PBMCs and/or SaOS- 2 cells might bind to their specific receptors on PBMCs to induce the signal transduction process, finally leading to the differentiation of PBMCs into osteoclasts. Macrophage colony-stimulating factor (MCSF) and receptor activator of NF- $\kappa$ B ligand 
(RANKL) are considered to be essentially involved in the differentiation phase of osteoclast precursors into osteoclasts [29]. However, recent study [30] revealed that TNF- $\alpha$ stimulates osteoclast differentiation in the presence of MCSF through a mechanism independent of RANKL. In that study, IL-1 was required to obtain actively resorbing osteoclasts. Therefore, IL-1 might stimulate osteoclast formation by both RANKL-dependent and -independent mechanisms. Various cytokines produced by PBMCs and SaOS-2 cells might cooperatively act on PBMCs to induce osteoclast differentation.

Unfortunately, we could not show the data for osteoclast formation from PBMCs transmigrated through endothelial cells after IL-1 activation. Further study is necessary to clarify these issues.

In conclusion, the present findings that IL- $1 \beta$ triggers both PBMC mobilization across HUVECs and their differentiation into osteoclast-like cells may give a new insight into studies concerning the mechanism of bone resorption in physiological as well as pathological states, such as osteoporosis and periodontal disease. Further elucidation of the role of PBMC mobilization and differentiation in the bone tissue may suggest novel therapeutic strategies for the treatment of diseases with bone loss.

\section{Acknowledgements}

The authors wish to thank to Dr. S. Kitazawa (Second Division, Department of Pathology, Kobe University School of Medicine) and Dr. M. Kanatani for their helpful advice. This work was supported in part by Grants-in-Aid from the Ministry of Science, Education, and Culture of Japan (No. 07671136), SRF in Japan and the Japanese Osteoporosis Foundation to T. Sugimoto.

\section{References}

1. Pierce AM, Lindskog S, Hammarstrom L (1991) Osteoclasts: structure and function. Electron Microsc Rev 4: 1-45.

2. Scheven BA, Visser JW, Nijweide PJ (1986) In vitro osteoclast generation from different bone marrow fractions, including a highly enriched haematopoietic stem cell population. Nature 321: 79-81.

3. Walker DG (1975) Bone resorption restored in osteopetrotic mice by transplants of normal bone marrow and spleen cells. Science 190: 784.

4. Alvarez JI, Ross FP, Athanasou NA, Blair HC, Greenfield EM, Teitelbaum SL (1992) Osteoclast precursors circulate in avian blood. Calcif Tissue Int 51: 48-53.

5. Helfrich $\mathrm{MH}$, Mieremet RH, Thesingh CW (1989) Osteoclast formation in vitro from progenitor cells present in the adult mouse circulation. J Bone Miner Res 4: 325-334.

6. Udagawa $\mathrm{N}$, Takahashi $\mathrm{N}$, Akatsu $\mathrm{T}$, Tanaka $\mathrm{H}$, Sasaki T, Nishihara T, Koga T, Martin TJ, Suda T (1990) Origin of osteoclasts: mature monocytes and macrophages are capable of differentiating into osteoclasts under a suitable microenvironment prepared by bone marrow-derived stromal cells. Proc Nat Acad Sci USA 87: 7260-7264.

7. Fujikawa Y, Quinn JM, Sabokbar A, McGee JO, Athanasou NA (1998) The human osteoclast precursor circulates in the monocyte fraction. Endocrinology 137: 4058-4060.
8. Quinn JM, Neale S, Fujikawa Y, McGee JO, Athanasou NA (1998) Human osteoclast formation from blood monocytes, peritoneal macrophages, and bone marrow cells. Calcif Tissue Int 62: 527-531.

9. Massey HM, Flanagan AM (1999) Human osteoclasts derive from CD14-positive monocytes. Br J Haematol 106: $167-170$.

10. Mundy GR (1993) Cytokines and growth factors in the regulation of bone remodeling. J Bone Miner Res 8: S505-S510.

11. Horiuchi T, Yoshida T, Koshihara Y, Sakamoto H, Kanai H, Yamamoto S, Ito H (1999) The increase of parathyroid hormone-related peptide and cytokine levels in synovial fluid of elderly rheumatoid arthritis and osteoarthritis. Endocr J 46: 643-649.

12. Cohen-Solal ME, Graulet AM, Denne MA, Gueris J, Baylink D, de Vernejoul MC (1993) Peripheral monocyte culture supernatants of menopausal women can induce bone resorption: involvement of cytokines. J Clin Endocrinol Metab 77: 1648-1653.

13. Pacifici R, Brown C, Puscheck E, Friedrich E, Slatopolsky E, Maggio D, McCracken R, Avioli LV (1991) Effect of surgical menopause and estrogen replacement on cytokine release from human blood mononuclear cells. Proc Nat Acad Sci USA 88: 51345138.

14. Kitazawa R, Kimble RB, Vannice JL, Kung VT, Pacifici R (1994) Interleukin-1 receptor antagonist and tumor necrosis factor binding protein decrease os- 
teoclast formation and bone resorption in ovariectomized mice. J Clin Invest 94: 2397-2406.

15. Takata S, Fukase M, Takagi Y, Tokunaga O, Fujita T (1990) Rapid $\mathrm{Ca}^{2+}$ refilling system of intracellular store(s) in human vascular endothelial cells. Biochem Biophys Res Commun 167: 933-940.

16. Takata S, Matsubara M, Allen PG, Janmey PA, Serhan CN, Brady HR (1994) Remodeling of neutrophil phospholipids with 15(S)-hydroxyeicosatetraenoic acid inhibits leukotriene $\mathrm{B}_{4}$-induced neutrophil migration across endothelium. $J$ Clin Invest 93 : 499-508.

17. Kaji H, Sugimoto T, Kanatani M, Miyauchi A, Kimura T, Sakakibara S, Fukasae M, Chihara K (1994) Carboxyl-terminal parathyroid hormone fragments stimulate osteoclast-like cell formation and osteoclastic activity. Endocrinology 134: 1897-1904.

18. Chuluyan HE, Issekutz AC (1993) VLA-4 integrin can mediate CD11/CD18-independent transendothelial migration of human monocytes. J Clin Invest 92: 2768-2777.

19. Hakkert BC, Kujipers TW, Leeuwenberg JFM, van Mourik JA, Roos D (1991) Neutrophil and monocyte adherence to and migration across monolayers of cytokine-activated endothelial cells: the contribution of CD18, ELAM-1, and VLA-4. Blood 78: 27212726.

20. Migliorisi G, Folkes E, Pawlowski N, Cramer EB (1987) In vitro studies of human monocyte migration across endothelium in response to leukotriene $\mathrm{B}_{4}$ and f-Met-Leu-Phe. Am J Pathol 127: 157-167.

21. Huffer WE (1988) Biology of disease; Morphology and biochemistry of bone remodeling: possible control by vitamin $\mathrm{D}$, parathyroid hormone, and other substances. Lab Invest 59: 418-442.

22. Stashenko P, Jandinski JJ, Fujiyoshi P, Rynar J, Socransky SS (1991) Tissue levels of bone resorptive cytokines in periodontal disease. J Periodontol 62: 504-509.
23. Spriggs MK, Nevens PJ, Grabstein K, Downer SK, Cosman D, Armitage RJ, McMahan CJ, Sims JE (1992) Molecular characterization of the interleukin-1 receptor (IL-1R) on monocytes and polymorphonuclear cells. Cytokine 4: 90-95.

24. Akeson AL, Mosher LB, Woods CW, Schroeder KK, Bowlin TL (1992) Human aortic endothelial cells express the type I but not type II receptor for interleukin-1 (IL-1). J Cell Physiol 153: 583-588.

25. Rodan SB, Wesolowski G, Chin J, Limujuco GA, Schmidt JA, Rodan GA (1990) IL-1 binds to high affinity receptors on human osteosarcoma cells and potentiate prostaglandin $\mathrm{E}_{2}$ stimulation of cAMP production. J Immunol 145: 1231-1237.

26. Granowitz EV, Clark BD, Vannier E, Callahan MV, Dinarello CA (1992) Effects of interleukin-1 (IL-1) blockade on cytokine synthesis: IL-1 receptor antagonist inhibits IL-1-induced cytokine synthesis and blocks the binding of IL-1 to its type II receptor on human monocytes. Blood 79: 2356-2363.

27. Ming WJ, Bersani L, Mantovani A (1987) Tumor necrosis factor is chemotactic for monocytes and polymorphonuclear leukocytes. $J$ Immunol 138: 1469-1474.

28. Rosales C, O'Brien V, Kornberg L, Juliano R (1995) Signal transduction by cell adhesion receptors. Biochimi Biophys Acta 1242: 77-98.

29. Suda T, Takahashi N, Udagawa N, Jimi E, Gillespie MT, Martin TJ (1999) Modulation of osteoclast differentiation and function by the new members of the tumor necrosis factor receptor and ligand families. Endocr Rev 20: 345-357.

30. Kobayashi K, Takahashi N, Jimi E, Udagawa N, Takami M, Kotake S, Nakagawa N, Kinosaki M, Yamaguchi K, Shima N, Yasuda $H$, Morinaga $T$, Higashio K, Martin TJ, Suda T (2000) Tumor necrosis factor $\alpha$ stimulates osteoclast differentiation by a mechanism independent of the ODF/RANKL-RANK interaction. J Exp Med 191: 275-285. 